\section{A COVID-19 JÁRVÁNY HATÁSAI A MAGYAR BIZTOSÍTÁSI PIACRA}

Kelemen Kitti (kikelemen@deloittece.com) és Németh Viktória (viknemeth@deloittece.com ), a Deloitte Zrt. Aktuáriusi és Biztositási Megoldások csapatának aktuáriusai

\section{ÖSSZEFOGLALÓ}

A hazánkban 2020 márciusában megjelent, kínai eredetű koronavírus következményeként kialakult helyzet a gazdaság összes szereplöjére hatással van, és ez alól a biztositók sem képeznek kivételt. Írásunk célja a biztosítótársaságok üzletmenetét érintő legfontosabb problémák feltárása és az ezekre alkalmazott megoldások bemutatása, ezzel átfogó képet nyújtva a hazai biztositási piaci gyakorlatról. Kutatást végeztünk a magyar biztosítók szakértőinek körében egy általunk összeállított kérdéssor mentén, amelyet minden esetben kétkörös virtuális beszélgetés követett egy-két hónapnyi eltéréssel, amelynek során a koronavírus várt és tapasztalt hatásait, valamint a kezdeti sokk utáni alkalmazkodás ütemét mértük fel. Törekedtünk minden lényegesnek vélt kérdéskört érinteni a biztosítási operációtól kezdve a szerződésállomány változásán keresztül az értékesítésre, termékekre és riportálásra gyakorolt hatásokig. Cikkünk elsősorban a 2020. május és július közötti felmérés során megismert információkra támaszkodik.

\section{SUMMARY}

The coronavirus appeared in Hungary in March 2020, which affects all participants in the economy, and insurers are no exception. The aim of our paper is to explore the most important problems affecting the business of insurance companies and to present the solutions applied to them, thus providing a comprehensive picture of the domestic insurance market practice. We conducted a survey among Hungarian insurers' experts along with a series of questions compiled by us, followed in each case by a two-round virtual discussion with a difference of one or two months, during which we measured the expected and experienced effects of the coronavirus and the pace of adaptation after the initial shock. We have sought to address all issues deemed relevant, from insurance operations to changes in contract portfolio to effects on sales, products and reporting. Our paper relies primarily on the information gathered during the survey.

Kulcsszavak: COVID-19, koronavírus, üzleti hatáselemzés, biztosításértékesítés, digitalizáció

Keywords: COVID-19, coronavirus, business impact assessment, insurance distribution, digitalization

JEL: G22, O16
DOI: $10.18530 /$ BK.2020.3-4.76

http://dx.doi.org/10.18530/BK.2020.3-4.76

\section{Bevezetés}

Az új típusú koronavírus 2019. év végi, kínai megjelenésekor még talán senki sem gondolta volna, hogy alig pár hónappal később a témából a Biztosítás és Kockázat folyóiratban cikk fog megjelenni. Amennyire távolinak és lokalizáltnak tünt kezdetekben a probléma, olyan gyorsan globális pandémiává nőtte ki magát. A járvány 2020 márciusában már szinte a világ minden pontján jelen volt, hatalmas egészségügyi és gazdasági károkat hagyva maga mögött. A megváltozott és megnövekedett kockázat, valamint a járvány terjedését enyhítö, a legtöbb országban alapelvként alkalmazott szociális távolságtartás értelemszerủen a biztosítási piacra is gyorsan begyürüzött, és a hatása szakmánkban a cikk szerzőinek jelenlegi érzése szerint beláthatatlan ideig és hosszú távú következményekkel lesz jelen.

Jelen tanulmányunk célja a COVID-19 járvány magyarországi biztosítási piacra gyakorolt hatásainak bemutatása. Ezen témában a piacon több rövidebb értekezés született már (Világgazdaság, 2020), azonban cikkünk megírásáig nem ismert az üzleti hatások bemutatásáról olyan átfogó anyag, amely nagyszámú piaci szereplő bevonásával készült. Jelen cikkünkkel egy olyan tanulmány megírását tüztük ki célul, amely a megkérdezett piaci szereplők szubjektív véleményének aggregált bemutatásán alapul, és összességében tükrözi a magyar biztosítási piac vélekedését a járvány rövid és hosszú távú üzleti hatásaival kapcsolatban. Tanulmányunkban többek között olyan érdekes kérdéseket érintünk, hogy hogyan fejlődött a cégek munkakultúrája a home-office időszaka alatt, az IT infrastruktúrák hogyan teljesítettek a távoli működtetés hatására, mennyire gyorsan adaptálódtak az úi, személyes kontaktus nélküli értékesitési helyzethez a biztosítók, valamint a biztositásértékesítők, vagy például hogyan hatott a koronavírus a riportálási folyamatokra. Hangsúlyt fektettünk arra, hogy a változtatások meg tudtak-e úgy valósulni, hogy a munkavállalók járvány miatt átalakuló egyéni érdekei, életkörülményei maximálisan figyelembe legyenek véve a munkaadók által.

Egyik kiemelt fókuszpontunk pedig az volt, hogy vajon a koronavírus felgyorsítja-e a biztosítók digitális evolúcióját.

\section{A felmérés módszere}

2020 májusában egy rövid, a COVID-19 addig ismert és tapasztalt hatásaira, valamint a várakozásokra koncentráló kérdőívvel kerestük meg a biztosítási piac szereplőit. A kérdések a következő főbb területeken mérték fel az üzleti hatásokat: biztosítási operáció működtetése (beleértve az IT infrastruktúrát érintő változásokat, projektek menedzselését és humán erőforrásokat), biztosításértékesítési folyamatok és szerződésállomány alakulása, biztosítási termékek szolgáltatásai, valamint riportálási elvárások. Az eldöntendő vagy pontozásos kérdések megvála- 
szolása után telefonos interjú keretében egyeztettük a legfontosabb és legérdekesebb felvetéseket a biztosítók szakértőivel. Mivel ekkor a vírus Magyarországon még csupán két hónapja volt jelen, tapasztalataink alapján a szakma nagy része még a kezdeti alkalmazkodási státuszban tartott. Az is látszott azonban, hogy nagy volumenủ és gyors módosításokra lesz szükség az operációs és értékesítési folyamatokban. Indokoltnak éreztük tehát, hogy felmérésünket egy későbbi időpontban is megismételjük, ezért július során ismét egyeztettünk a szakértőkkel, és feltérképeztük a fejlődést a májusi állapotokhoz képest.

A felmérésben hét biztosító szakértői vettek részt, akikkel az életbiztosítási és a nem-életbiztosítási üzletágakat érintő kérdéseket is érintettük. A válaszadó biztosítók a 2019. év végi bruttó díjelőírásuk alapján a magyar biztosítási piac 45,4 százalékát fedik le a MABISZ által publikált adatok szerint. A közreműködő szakértőknek ezúton is szeretnénk megköszönni a nyitottságukat és ezen cikk létrejöttéhez nélkülözhetetlen hozzájárulásukat.

Jelen cikkünkben a felmérés eredményeit mutatjuk be, a válaszok anonim összesítésével és elemzésével.

\section{Biztosítási operáció müködtetése}

A vírus által kialakult helyzet miatt a vállalatok egyik pillanatról a másikra home-office működésre kényszerültek, ami több tekintetben is kihívásokat jelentett a mindennapi üzletmenet során. Felmérésünk az operáció működése kapcsán (amely alatt a biztosítási szerződések kezelését és az ehhez szükséges infrastruktúra működtetését értjük) egyrészt kitért a jelenlegi helyzet indokolta digitalizációs, automatizációs fejlesztések szükségességére, másrészt az úgynevezett agilis munkavégzés felé történő elmozdulásra (Hernády - Vanczák, 2020). Válaszokat vártunk több, a müködést befolyásoló területet érintve a vírus által kialakult helyzet hatására, többek közt kiberbiztonság, IT alkalmazás architektúra, infrastruktúra, munkavállalók együttműködése, illetve hatékonysága, valamint a projektek megvalósulása szempontjából. Ezen kérdésekre adott válaszok darabszám szerinti megoszlását szemlélteti az 1. ábra. A visszajelzések alapján több kritikus pontot azonosítottunk a biztosítók operatív müködése kapcsán.

1. ábra: Mekkora nehézséget okozott a vírus által kialakult helyzet az operáció müködése szempontjából?

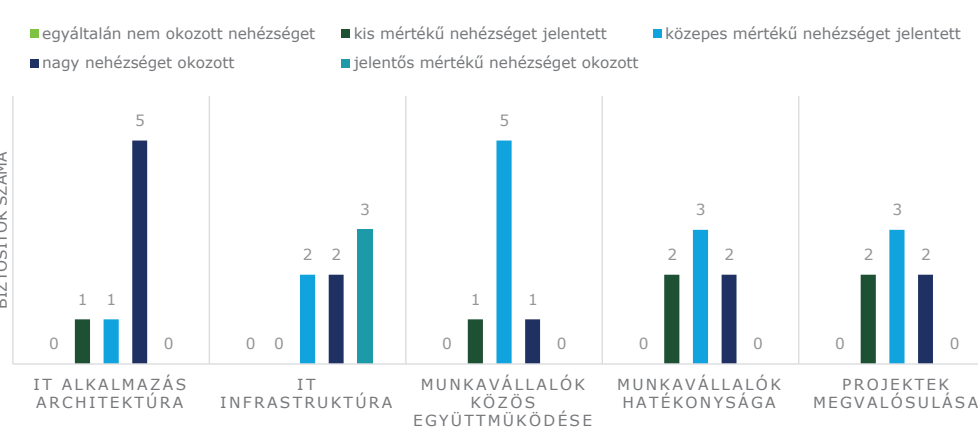

Forrás: A Deloitte-nak a COVID-19 járvány hatásait felmérỏ kérdőívére kapott válaszok
A részt vevő hét biztosító válaszai szerint az első hetekben a legnagyobb nehézséget a megfelelő IT infrastruktúra, valamint alkalmazás architektúra kiépítése jelentette. A legtöbb biztosítónál új laptopok vásárlására volt szükség a munkavállalók számára, ugyanis többen még asztali számítógép mellett dolgoztak az irodában. Emiatt hirtelen kényszerü laptopbeszerzések történtek, amelyek jelentős, előre nem tervezett mértékű anyagi ráfordításnak bizonyultak. A hardverek beszerzése azonban csak egy kezdeti lépés volt, ezen felül a már meglévő és újonnan vásárolt gépeket és az infrastruktúrát is fel kellett készíteni az otthoni működésre. Kiberbiztonság szempontjából ugyancsak lényeges feladatok hárultak a rendszergazdákra és informatikusokra a kommunikációs és egyéb szoftverek telepítésének következtében. Mivel sok esetben a kommunikációs eljárások kialakítása is szükségszerűvé vált, emiatt új kommunikációs csatornák kerültek bevezetésre (Skype for Business, Microsoft Teams, Zoom), amelyekhez a munkavállalóknak gyorsan kellett alkalmazkodniuk. Az informatikai hálózat távoli elérésének lehetővé tétele szintén okozott nehézségeket, nagy kihívást jelentett kezdetben a megfelelő távoli hálózat elérés („VPN”, azaz Virtual Private Network) kialakítása. Ennek leküzdése érdekében előfordult olyan megoldás is a piacon, hogy a munkavállalók a home-office-ban töltött időszak első heteiben több müszakban, felváltva dolgoztak, ezzel tehermentesítve a rendszereket. Több szoftver, egyebek mellett néhol az aktuáriusi cash-flow modellezéshez használt szoftverek távoli elérése okozott fennakadást eleinte.

Előfordult olyan megoldás is a piacon, hogy a munkavállalók a home-office-ban töltött időszak első heteiben több müszakban, felváltva dolgoztak, ezzel tehermentesítve a rendszereket.

A távmunkában való munkavégzés a munkavállalói oldalon is jelentős változás volt, a munkavállalók együttműködése nehézkes volt, és hatékonyságromlást okozott. Főként a kisgyermekes családok esetében a munkaidő esetenként eltolódhatott, vagyis a napi munkavégzés nem a korábbiakban megszokott idősávban, hanem ettől eltérően, esetleg korábbi vagy még későbbi kezdéssel, akár éjszakába nyúlóan zajlott, ezzel nehezítve a kollégák, projektcsapatok együttműködését. Az új munkakörülményekhez való alkalmazkodás, illetve a szükséges, újonnan telepített szoftverek használatába történő betanulás a munkavállalókat kihívások elé állították, bele kellett szokni az új működésbe. Ez a helyzet az eddigieknél nagyobb rugalmasságot igényelt mindenki részéről. Emiatt több biztosítónál történt elmozdulás az agilis munkavégzés irányába, azonban csak keveseknél volt előzetes tréning az új munkamódszerre való átállás előkészítésére. Ezen munkamódszer bevezetésének fö okaként a munkavégzés hatékonyságának növelése nevezhető meg, amelyet a távolról való munkavégzés sikerességének támogatása különösen indokolt, de kétségtelen, hogy jobb követhetőséget is biztosít a projektek szempontjából. Mindezek mellett fontos megemlíteni, hogy elöfordult olyan részleg is, ahol ez a fajta müködés sokkal hatékonyabbnak, könnyebbnek bizonyult a korábbiakhoz képest, például a telefonos ügyfélszolgálatok (call center) esetében. 
Mindezek mellett a megkérdezett biztosítók előrelépést tapasztaltak a munkakultúra fejlettségét tekintve, szervezettebben, hatékonyabban kezdtek el dolgozni a kollégák, a megbeszélések is célzottabbá váltak. Ezzel szemben a virtuális munkakörnyezetben az információáramlás eleinte érezhetően lassabban zajlott. A merev munkavégzési szabályok enyhültek, inkább a feladatmegoldás került előtérbe a munkaidő kereteivel szemben. Kezdetben azonban problémát jelentett ebben a sokak számára még ismeretlen helyzetben egy új rutin kialakítása, tekintve, hogy voltak olyanok is, akik korábban nem találkoztak a home-office adta lehetőséggel. Egyes esetekben ez a vezetőség részéről eddig elképzelhetetlennek számított, ám a járvány okozta kényszerhelyzetben világossá vált, hogy ez csak egy előzetes tévképzet, és valószínűleg a jövőben már ezen munkavállalók számára is megjelenik a home-office mint opció. Ez a helyzet a vezetőket is megpróbáltatás elé állította, hiszen ki kellett találniuk, hogyan lehetséges a mindennapi munkamenetet így irányítani, és a projektek sikeres végrehajtását továbbra is biztosítani.

A megkérdezett biztosítók tapasztalatai alapján a vírus által kialakított körülmények között a már futó projektek lassabban haladtak, hiszen sokkal több időre van szükség személyes kontaktus nélkül az egyes folyamatok menedzselésére, visszajelzésekre, döntésekre. Másrészt sok esetben háttérbe helyeződtek az eredetileg beütemezett projektek, és a jelenlegi szituációra történő reflektálásra helyeződött a fókusz. Ez nem jelenti azt, hogy ezek a projektek végleg befejeződtek, csak tolódtak időben. Az IFRS 17 projektek haladását és ütemezését többségében nem befolyásolta sem a bevezetés határidejének elhalasztása ${ }^{1}$, sem a járványhelyzet.

Új, a helyzetre reflektáló projektek helyeződtek fókuszba, a digitálizáció kulcsfontosságú eleme lett a mindennapoknak. Több biztosítónál elindult vagy terítékre került olyan digitális megoldások fejlesztése, melyek eddig háttérbe szorultak, a kialakult helyzet miatt azonban nagyobb támogatást, lendületet kaptak. Ezekről javarészt korábban is volt gondolkodás, de most váltak igazán fontossá, a későbbi működést tekintve talán nélkülözhetetlenné. A digitalizáció részének tekinthető a szervezeti működés szempontjából eddig papír alapon végbemenő folyamatok megújítása, mint például a munkaidő-nyilvántartás és a bérpapír, amire még mindig létezik precedens. Az értékesítés támogatását segítő digitális megoldásokra a következő, „Értékesítés” részben térünk ki részletesen.

Eleinte nagyobb mértékű költségcsökkentésre sem kényszerítette a felmérésünkben részt vevő biztosítókat a lelassult gazdasági környezet, habár esetenként történtek visszavágások a rendezvények, csapatépítők és reprezentációs költségek tekintetében. A jövőre vonatkozóan már több iparághoz hasonlóan a kezdetekben felmerült az irodabérlési költségcsökkentés a távmunka esetleges előtérbe kerülése esetén.

Humán erőforrás oldalról kétségkívül nagyobb odafigyelést igényelt ez az időszak, ami pozitív hozadékként említhető, hiszen nagyobb hangsúly helyeződött az emberi oldalra. A cégek vezetői sokat dolgoztak azon, hogy mindenkinek megfelelő munka- környezetet sikerüljön kialakítani. Az új körülmények között a stressz elfogadható kezelése, illetve az emberi kapcsolatok is előtérbe kerültek.

Néhány hónap elteltével úgy tűnik, kezd minden visszaállni a körülményekhez képest normál kerékvágásba, lassan stabilizálódni látszanak az újonnan bevezetett folyamatok is. Továbbra is többségében az otthoni munkavégzés a jellemző, a visszatéréssel inkább óvatosak a megkérdezett biztosítók. Van, ahol már életbe lépett egy új rendszer a home-office és az irodából történő munkavégzés optimális arányára, míg máshol erre vonatkozóan szeptembertől lesznek iránymutatások. Előkészületeket már látni az otthoni munkavégzésből fakadó előnyök kiaknázására. Korábban a biztosítók irodáinak kapacitásbővítése volt a tendencia, azonban most már szinte sehol sem tartják lehetetlennek, hogy az eddigi munkaállomások számát lecsökkentsék, ugyanis vannak elég jól körülhatárolható pozíciók, feladatkörök, amelyeknél nagyon jól működik a távmunka. Ezzel csökkentenék a bérleti díjakat vagy akár a saját tulajdonú ingatlan bérbeadásából pluszbevétel szerzését tennék lehetővé a biztosítók. Néhol már született minden munkavállalót érintő költségcsökkentési döntés is. Ennek kapcsán is nagyfokú bizonytalanság tapasztalható a piacon, de folyamatos tervezés és felülvizsgálat történik a költségeket illetően. Jelenleg a legnagyobb kihívás az optimális munkarend, illetve a munkavállalók motívációjának fenntartása. Kezdetben megfigyelhetően nagyobb volt a hatékonyság a kijárási korlátozás kezdetén, azonban a munkavállalók produktivitása pár hónap elteltével és a tilalom enyhítésével a tapasztalatok alapján visszaállt a járvány előtti szintre. Még mindig érezhető egyfajta bizonytalanság, ami talán már kisebb mértékű, mint márciusban a járványhelyzet elején, de hogy meddig nyúlik el, és hosszú távon milyen hatással lesz a biztosítók operatív működésére, előre nem, vagy csak kis valószínűséggel megjósolható.

\section{Értékesítés}

A koronavírus okozta kijárási korlátozás, valamint a megfertőződéstől való félelem jelentős akadályt gördített a biztosítási termékek személyesen történő értékesítésének útjába, esetenként teljesen le is állította azt a világ minden táján.

A McKinsey tanulmánya (McKinsey, 2020) szerint a német és amerikai biztosításértékesítők új szerzéseire is jelentős csapást mért a pandémia által kialakult helyzet. A német biztosításértékesítők új szerződéskötéseinek darabszáma például több mint 40 százalékot esett egy 2020 áprilisában elvégzett felmérés szerint, az egy évvel korábbi értékekhez képest. A magyar biztosítók első negyedéves aggregált adatain (MNB, 2020) még nem érzékelhető ilyen drasztikus visszaesés, sőt, a biztosítók teljes szerződésállomány darabszámában 2,5 százalékos növekedés tapasztalható az egy évvel korábbi azonos időszakhoz képest, ami közel 356 ezer új szerződést jelent. Ez a növekedés döntően a nem-életbiztosítási üzletág 3,3 százalékos szerződésszám-növekedésének a következménye, ugyanis az életbiztosítási üzletág szerződéseinek darabszáma 1,1 százalékos csökkenést mutat 
az előző évhez képest. Itt megjegyezzük, hogy az idei első negyedéves értékesítési eredményekre még nem hatott jelentősen a koronavírus Magyarországon, illetve a bemutatott tendencia összhangban van az elmúlt évek állományalakulásával. Az év második negyedévében is hasonló tendenciát tapasztaltak a felmérésünk során megkérdezett biztosítók. Megkérdezésünkkor zömében az életbiztosítási termékek új szerzésének enyhe visszaeséséről számoltak be.

Már piacra is kerüiltek különböző megoldások a szerződéskötési folyamat egyes részeinek vagy egészének digitalizálása tekintetében.

A személyes találkozás lehetőségének hiánya az életbiztosítások értékesítését gátolta jelenősebben, ahol mindmáig a klasszikus, személyes tárgyalás alapú értékesítési forma dominálja a piacot, szemben a nem-életbiztosítási piac jelentősebb online eladás részesedésével. Azonban a korábban sokáig halogatott fejlesztések a pandémia miatt előtérbe kerültek, és több biztosító is elindította a tervezett fejlesztések megvalósítását a kijárási korlátozás első heteiben. Ezek eredményeképpen már piacra is kerültek különböző megoldások a szerződéskötési folyamat egyes részeinek (igényfelmérés, ajánlattétel, kockázatfelmérés, szerződés létrejötte) vagy egészének digitalizálása tekintetében. Az egyes terméktípusok esetében is eltérő megoldásokat alkalmaztak a biztosítók, figyelembe véve a jogszabályi kötelezettségeket. Több biztosítónál sikerült teljesen papírmentessé tenni az ajánlattételi és szerződéskötési folyamatot, ennek kapcsán az elektronikus aláírás is bevezetésre került. Egyes biztosítóknál az ügyfélazonosítás személyes kapcsolat nélküli, online megvalósítására is történtek fejlesztések, amelyet rögzített videófelvétellel oldottak meg.

A felmérésünk során megkérdezett biztosítóknál nem történt szignifikáns változás a biztosításértékesítők számában, azonban az aktivitásukat eltérően befolyásolta a helyzet. A kérdőívünk ezen témakörre irányuló kérdésére kapott válaszokat összesítjük a 2. ábrán. Az értékesítők részéről nagy rugalmasságot kívánt a hirtelen bekövetkezett körülményekhez való alkalmazkodás. A személyes tanácsadásokat felváltotta a telefonon vagy videós chaten történő kommunikáció, a mely növelheti az ügyfélélményt.

Hosszú távon mindenképpen kérdéses lesz, hogy a jelenlegi formában hogyan lehet fenntartani a szolgáltatások magas minőségét, illetve hogy a vírus elvonulása után mennyire épül be az általános működésbe a virtuális értékesítés, és milyen irányba változik majd a személyes kapcsolat, valamint a biztosítási ügynökök szerepe az értékesítésben, különösképpen az életbiztosítások értékesítése kapcsán. Ezt a területet egyéb adójogszabály-változtatások ${ }^{2}$ is érintik napjainkban, ami a biztosításértékesítők helyzetét tovább nehezíti, és a cégek javadalmazási politikáját átgondolásra készteti.
2. ábra: Hogyan befolyásolta a vírus által kialakult helyzet a biztosításértékesítők aktivitását?

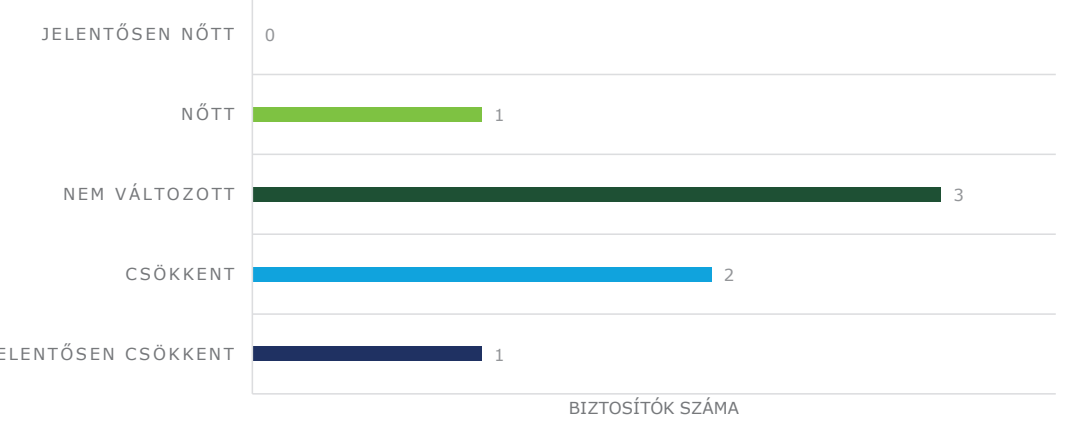

Forrás: A Deloitte-nak a COVID-19 járvány hatásait felmérő kérdőivére kapott válaszok

\section{Biztosítási termékek szolgáltatásai}

A járványhelyzet első heteiben sokakat foglalkoztató kérdés volt, hogy a meglévő kockázati biztosítások milyen fedezetet nyújtanak a koronavírus-fertőzöttségre, valamint a keresőképtelenség esetére. Emellett, mivel munkahelyek tömege szűnt meg, készülve a hosszabb távú gazdasági recesszióra és a megtakarítások esetleges felélésére, a megtakarítási jellegű szerződések esetén igénybe vehető díjfizetés-könnyítési, valamint -megszüntetési lehetőségekről érdeklődtek nagy számban az ügyfelek. A biztosítók tapasztalatairól ebben a témában részletesebben cikkünk „Szerződésállomány alakulása” fejezetében írunk. A fogyasztói igényekhez alkalmazkodva több biztosító palettáján is új biztosítási termékek jelentek meg mind élet-, mind nem-életbiztosítási ágon, amelyek a koronavírus közvetett, valamint közvetlen hatásai ellen nyújtanak védelmet. Ez nem minden esetben jelenti azt, hogy önálló termékek kerültek bevezetésre, nagyrészt az opcionális vagy kötelezően beépített fedezetekben történtek módosítások, vagy kiegészítőkkel bővült a biztosító palettája.

Az ügyfelek néhány biztosító esetében már térítést kaphatnak COVID-19 fertőzöttség esetén, egyes biztosítások kórházi napi térítést nyújtanak koronavírus miatti betegség következtében fellépő kórházi ellátásra, valamint abban az esetben is szolgáltat az adott biztosító, ha a koronavírus miatti betegség következtében keresőképtelenné válik a biztosított.

Mivel a koronavírus elterjedése a külföldi utazásokat erősen korlátozta, nem meglepő, hogy az utasbiztosítások piaca jelentősen visszaesett. Ahogy a világ újra kinyitotta a kapuit, és az utazásra egyre nagyobb lehetőség nyílt, több biztosító is újragondolta az elérhető utasbiztosításait. Egyes biztosítóknál újításnak számít például, hogy már nemcsak külföldi útjainkra köthetünk biztosítást, hanem a megnövekedett belföldi turizmusra reflektálva, akkor is tudunk szerződni, ha magyarországi úticélt tűztünk ki. Találunk továbbá olyan utasbiztosítási terméket a piacon, amely fedezetet nyújt a külföldi járványügyi vészhelyzet miatti azonnali hazautazással kapcsolatos költségekre, a külföldi karanténintézkedések miatti 
többletköltségekre és a COVID-19 fertőzésből adódó megbetegedés vagy hatósági karantén miatt felmerülő utazásképtelenség esetén meg nem térülő szállás- és utazási költségekre. Az otthoni munkavégzés hozadéka továbbá több biztosító esetében is a lakásbiztositási termék kiegészítése, hogy a lakásban tartott értékek - ideértve a céges tulajdonban lévő eszközök biztonságát is - nagyobb hangsúlyt kapjanak.

Az új termékek fejlesztése mellett több biztosítónál is felmerült a meglévő termékeik szerződési feltételeinek újragondolása. Módosításokat alkalmaztak például a várakozási időben (egyes biztosítók óvatos megközelítést alkalmazva növelték a szerződési feltételekben megfogalmazott várakozási időt, amely időszakban csak baleseti halál esetén történik kifizetés), a kockázatkizárások megfogalmazásában (egyes termékeknél COVID-19 fertőzöttek nem köthetnek szerzödést), valamint díjfizetés-könnyítések tekintetében is (az ügyfelek hosszabb ideig maradhatnak díjjal nem fedezett, de kockázatban álló státuszban, anélkül hogy a biztosító letörölné a szerződést, azaz a respiró idő növekedett).

A koronavírus nyomán kialakult gazdasági helyzet egyes szektorok befektetéseit jelentős mértékben befolyásolta, erre reflektálva azonban a megkérdezett biztosítók nem tervezték unit-linked termékek esetén új választható eszközalap bevezetését a portfóliójukba. Érdekes kérdés lehet, hogy a koronavírus hosszabb távú hatására a biztosítók eszközalap-kínálata hogyan fog változni, illetve hogy az ügyfelek mennyire tudatosan fognak átváltani a megváltozott trendek hatására.

\section{Riportálás}

A kialakult bizonytalan gazdasági helyzetre való tekintettel a biztosítótársaságok anyavállalatai, valamint a helyi vezetőségek elvárásai szigorúbbak lettek a riportálás terén, rendszeresebb és részletesebb kimutatásokat vártak el a tőkehelyzetük és portfóliójuk folyamatos monitorozása érdekében. A biztosítók aktuáriusainak több lehetséges szcenárióra kiterjedő számítást kellett elvégezniük kezdetben, azonban a helyzethez való adaptálódást követően ezek a szigorítások egyre enyhülni látszódtak. Az ORSA riport összeállításánál is figyelembe kellett venni a fennálló körülményeket, a biztosítók az ORSA bizonyos részeit frissítették, de néhány szereplő rendkívüli ORSA riportot is készített a COVID-19 járvány hatásai miatt.

Mindezeket a plusz teendőket és az otthoni munkavégzés okozta kezdeti nehézségeket is figyelembe véve, a kérdőívünkre adott válaszok alapján a biztosítók nem érezték úgy, hogy az év végi zárási folyamataikat jelentősen nehezítette volna a kialakult helyzet. A 2019. év végi, valamint 2020. első negyedéves Szolvencia II riportálási határidőket az EIOPA javaslatára az MNB eltolta ${ }^{3}$, ezáltal több idő állt a biztosítók rendelkezésére a QRT táblák előállítására, valamint az adatszolgáltatás további elemeire is. A biztosítók az így kapott időbeli haladékot azonban sok esetben nem használták ki, ugyanis már az eredeti határidőre végeztek a feladataikkal.

A stratégiai tervezés folyamata, valamint a Szolvencia II-es tartalékolás és tőkeszükséglet-számítás azonban nem elhanyagolható mértékben fog változni, és bizonyos esetekben akár a számviteli tartalékok is érintettek lehetnek az események tükrében (3. ábra). A stratégiai tervezés a megszokottnál több tervezéssel és újraszámolással jár, a tőkeszükséglet esetében a tőkepiaci események következtében kialakuló eszközoldali sokkok, a tartalékolás esetében pedig a különböző cégspecifikus tartalékok okozta nehézségekkel, valamint a hosszú távú feltételezések megfelelő meghatározásával kell megbirkózniuk a biztosítóknak.

3. ábra: Mekkora hatással van a vírus által kialakult helyzet az aktuáriusi számításokra?

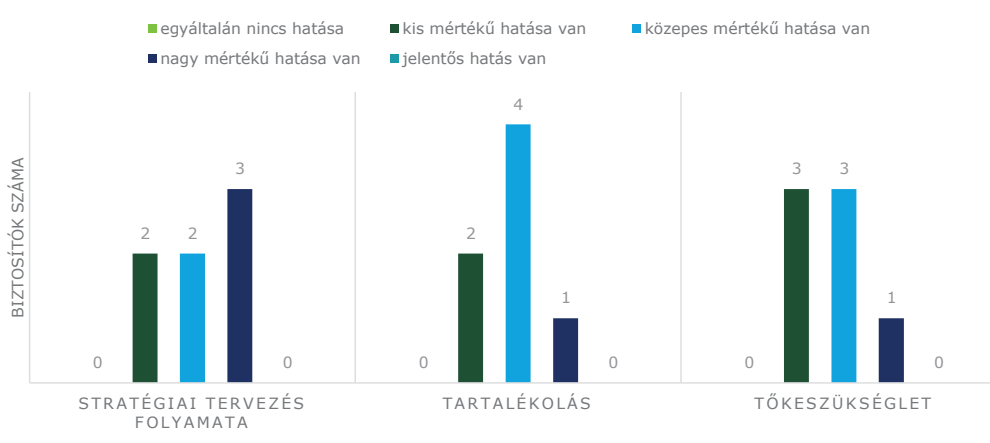

Forrás: A Deloitte-nak a COVID-19 járvány hatásait felmérő kérdőívére kapott válaszok

\section{Szerződésállomány alakulása}

A koronavírus által kialakult helyzet az életbiztosítási üzletág szerződésállományára volt nagyobb hatással. Az új szerzések darabszáma bizonyos mértékben csökkent (4. ábra), hiszen a személyes értékesítést akadályozta a kijárási korlátozás, az új fejlesztésekkel helyenként lehetővé váló virtuális üzletkötésre való átálláshoz pedig mind az ügyfeleknek, mind a tanácsadóknak hozzá kell szokniuk.

A kérdőívünkre kapott visszajelzések azt mutatják, hogy egyes biztosítók tapasztaltak egy visszavásárlási, illetve törlési hullámot az életbiztosítási szerződéseik kapcsán a járvány miatti korlátozások első heteiben. Az azóta eltelt időszakban azonban ez a hullám kisimulni látszódik, és a visszavásárlások, törlések darabszáma stabilizálódott a járvány előtti vagy annál valamennyivel magasabb szinten. Ugyanakkor általánosabb következtetések levonása még korai lenne, a hosszú távú életbiztosítási szerződések esetében ilyen rövid időn belül még nem feltétlenül mutatkoznak meg a számszerű hatások. A gazdasági recesszió elnyúlásával azonban számíthatunk arra, hogy a jövőben ez változni fog, és az emberek a megtakarításaik felélésére kényszerülve esetleg részben vagy egészben visszavásároltatják megtakarítási jellegü életbiztosítási szerződéseiket, vagy felfüggesztik azok díjfizetését, esetleg díjcsökkentéshez folyamodnak.

Nem-életbiztosítási területen a kötelező gépjárműfelelősség-biztosítás, egyéb gépjármü-biztosítás és utasbiztosítás termékek értékesítése esett vissza legszembetűnőbben, ezeknek már számszerűsíthető a hatása. (5. ábra) Ennek eléggé kézenfekvő okai vannak, 
amelyek többek között a külföldi utazások korlátozása és az új- és használtautó-piac viszszaesése a kijárási korlátozás bevezetésével. Több biztosító is javulást tapasztalt a kgfb és casco szerződések kárhányadain főleg az alacsonyabb kárgyakoriság miatt, ugyanis a jármüforgalom jelentősen csökkent a március, április és május hónapokban. A krízishelyzet enyhülésével a kárdarabszámok kezdenek visszaállni a korábbi szintre, egyes biztosítók azonban magasabb összegü károkat tapasztaltak az elmúlt hónapban. Ennek egy lehetséges okozója az euró árfolyamának növekedése következtében fellépő gépjárműalkatrész-drágulás, másrészt a szervizek díjszabását befolyásolhatja a korábbi bevételkiesés kompenzációja. Kezdetben a biztosítók számítottak arra, hogy lesznek majd késve bejelentett káraik, különösen a külföldön bekövetkezett károk esetében. Néhány hónap távlatában ilyen kárbejelentésekre nem került sor tömegesen, de a biztosítók aktuáriusai továbbra is óvatos megközelítést alkalmaznak a kártartalékolás tekintetében.

4. ábra: Hogyan alakult az új szerzések darabszáma életbiztosítási területeken?
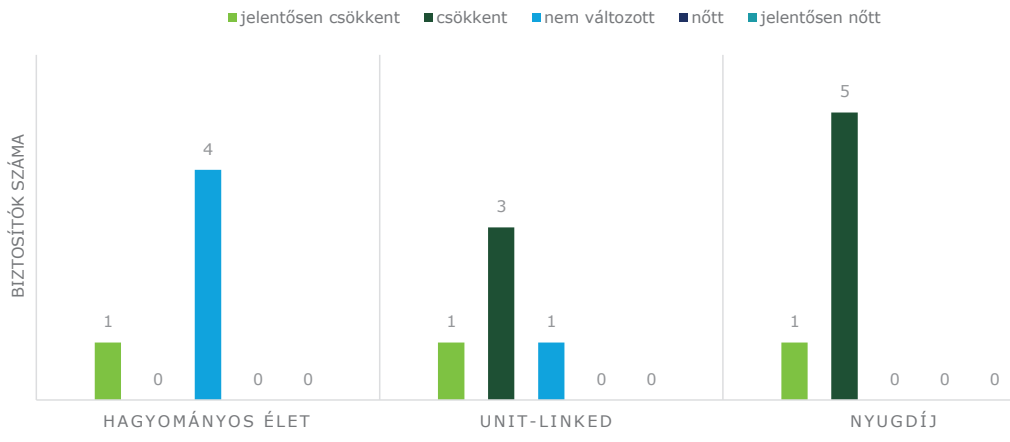

Forrás: A Deloitte-nak a COVID-19 járvány hatásait felmérő kérdöivére kapott válaszok

5. ábra: Hogyan alakult az új szerzések darabszáma nem-életbiztosítási területeken?

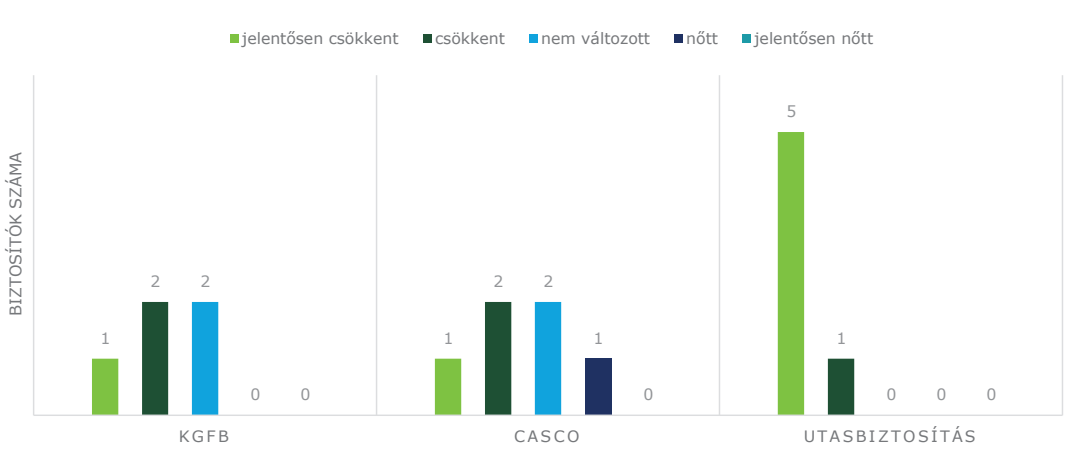

Forrás: A Deloitte-nak a COVID-19 járvány hatásait felmérỏ kérdőivére kapott válaszok

\section{Összegzés}

Összességében a COVID-19 járványnak nem csupán negatív hatásai voltak a biztosítók működésére és eredményére nézve, számos pozitív tapasztalatról számoltak be a megkérdezett biztosítók. Mindenképpen ki kell emelni pozitívumként a biztosítók részéről a home-office működésre való átálláshoz szükséges megfelelő informatikai háttér megteremtését és az akadályok gyors és hatékony leküzdését. Olyan digitalizációs fejlesztéseket hajottak most végre a biztosítók, amelyeket már hosszú ideje terveztek, de a járvány beköszöntével szükségszerűvé vált a megvalósításuk, hogy továbbra is hasonló szinten tudják fenntartani a működésüket. Hosszabb távon is megmutatkozhat a belső informatikai eszközök beszerzésének és a rendszerek bővítésének a pozitív hatása, hiszen sok cég pozitívan értékelte a távoli munkavégzést. A munkavállalók hatékonyságát a legtöbb esetben nem befolyásolta az irodán kívüli munkamenet, a kezdeti alkalmazkodást követően a folyamatok zömében gördülékenyen haladtak. Emiatt az otthoni munkavégzés beépülhet a mindennapokba a járvány elvonulása után is, hiszen a feltételek már adottak hozzá, ezzel pedig költséget is csökkenthetnek a biztosítók, ugyanis az irodák bérleti díja jelentős tétel a kiadások listáján. Az új helyzet sok esetben elörelépést eredményezett a munkakultúrában is, a merev munkavégzési szabályok lazultak, és több helyen egyre rugalmasabb a hozzáállás mind a munkáltató, mind pedig a munkavállaló oldaláról.

Több biztosító vezetősége tett lépéseket a munkavállalóik kényelmének és egészségének megőrzésére is. E célból egyes biztosítók ingyenes szájmaszkokat biztosítottak a munkavállalóik számára, illetve megszervezték a cég menzáján kapható ebéd házhoz szállítását.

Emellett persze nem lehet szemet hunyni az elkerülhetetlen negatív hatások felett sem. Kezdetben problémák léptek fel a belső hálózat és egyes aktuáriusi szoftverek távoli elérésével kapcsolatban, ezek helyreállítása nagy erőfeszítéseket igényelt a biztosítók informatikusai részéről. Jelentősek a gazdasági helyzetre mért negatív hatások is, ezek közül sok még nem is mutatkozott meg, azonban hosszú távú következményekkel számolni kell, és azoknak a mértéke továbbra is bizonytalan. Bár számos alternatív megoldás jelent meg a piacon életbiztosítási termékek értékesítésére, a személyes értékesítés visszaesése több biztosító új szerzéseinek darabszámára is láthatóan negatívan hatott.

Összességében elmondható, hogy a koronavírus magyarországi megjelenésekor tett előzetes várakozásokkal ellentétben egyelöre enyhébb hatások tapasztalhatóak 2020 júliusáig.

Magyarországon a járványhelyzet okozta válság elején, két meglehetősen közeli időpontban mértük fel a hatásokat a piacon annak érdekében, hogy ez a cikk a Biztosítás és Kockázat folyóirat jelen számában megjelenhessen. Azonban a hosszú távú hatásokat figyelemmel követve megcélozzuk azok későbbi felmérését és elemzését is a pandémia későbbi státuszaiban, hiszen a következmények nagy része még nem számszerüsíthető teljes mértékben, és negyedév távlatából messzemenő, főként hosszú távú következtetés nem is vonható le. 


\section{HIVATKOZÁSOK}

'Az IASB (International Accounting Standards Board) 2020. március 17-i döntése alapján a bevezetés határideje egy évvel későbbre, 2023. január 1-jére tolódott.

2020. július 3-án elfogadott központi költségvetés megalapozásáról szóló törvény szerint változnak a kisadózó vállaalkozások vonatkozó szabályozások.

作 szolgáltatásának határidejét két hónappal meghosszabbitták.

\section{IRODALOMJEGYZÉK}

Hernády Balázs-Vanczák Gergely Pál: Az agilitás vizsgálata a biztositási szektorban. Biztositás és Kockázat, 2020. 3-4. szám

Magyar Biztositiok Szzövetségege (2020)
Online: https://mabisz-hu/wp-content/uploads/2020/05/MABISZ-Biztositási-piac-2019Q4.pdf Letölttve: 2020. július 21.

Magyar Nemzeti Bank (2020)

Online: https://sta.mnb.hu/Reports/powerbi//sTA-SF/Bare for the next distribution model

Online: https://www.mckinsey.com/industries/financial-services/our-insights/how-insurance-can-prepare-for-the-next-distribution-model?

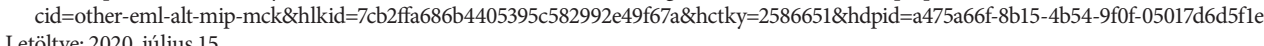
Világgazdaság (2020): A digitalizáció a megoldás a biztositóknál

Online:https://www.gg.hu/vilaggazdasag/vilaggazdasag-penzugy/a-digitalizacio-a-megoldas-a-biztositoknal-2242810/ Letöltve:2020. május 11

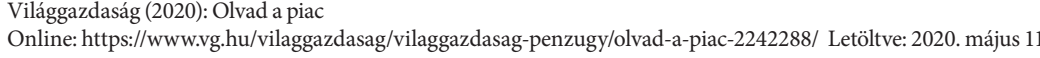

